Aspirasi: Jurnal Masalah-Masalah Sosial | Volume 9, No, 2 Desember 2018

ISSN: 2086-6305 (print) ISSN: 2614-5863 (electronic)

DOI: https://doi.org/10.22212/aspirasi.v7il.1084

link online: http:/jurnal.dpr.go.id/index.php/aspirasi/index

\title{
DETERMINAN SIKAP TINDAK KEKERASAN DALAM RUMAH TANGGA DI PROVINSI BANTEN
}

\author{
Determinant of the Attitude of Domestic Violence \\ in Banten Province
}

\author{
Fini Fajrini, RR. Arum Ariasih, Noor Latifah A. \\ f_fajrini@yahoo.com \\ Fakultas Kesehatan Masyarakat Universitas Muhammadiyah Jakarta \\ Jl. K.H. Ahmad Dahlan Ciputat Tangerang Selatan Banten
}

Naskah Diterima: 10 Oktober 2018 | Naskah direvisi: 4 Desember 2018 | Naskah diterbitkan: 31 Desember 2018

\begin{abstract}
Violence against women is a major public health problem worldwide. Result of the National Commission on Violence Against Women's 2017 mapping showed that violence against women spreads more widely, in various types, causing traumatic scars, and the number continues to grow reaching 348.446 cases. This research aims to analyze the relations between individual, family, and community basis with supportive attitude toward domestic violence. Domestic violence in Banten Province is relatively high, from 2010 to September 2017 reaching 442 cases. Data analysis was carried out on married men and women, a total of 1.876 in Banten Province's 2012 Indonesian Demographic Health Survey. IDHS used a cross-sectional design and the statistical analysis employed logistic regression. The results showed that supportive attitude were widely welcomed at individual basis (women younger age, low education, younger of age at first marriage, and living in rural areas) as well as at family basis (being a sole decision maker).
\end{abstract}

Keywords: domestic violence, attitudes toward domestic violence, logistic regression, individual basis, family basis, community basis

\begin{abstract}
Abstrak: Kekerasan terhadap perempuan merupakan masalah kesehatan masyarakat yang utama di seluruh dunia. Hasil pemetaan Komnas Perempuan tahun 2017 di seluruh Indonesia, menunjukkan bahwa persebaran kekerasan terhadap perempuan semakin luas, bentuknya semakin beragam, bekas traumanya mendalam, dan jumlahnya terus berkembang mencapai 348.446 kasus. Kekerasan dalam rumah tangga di Provinsi Banten tergolong tinggi terhitung dari tahun 2010 hingga September 2017 mencapai 442 kasus. Penelitian ini bertujuan untuk mengetahui hubungan faktor individu, keluarga, dan masyarakat dengan sikap setuju terhadap kekerasan dalam rumah tangga. Analisis data dilakukan pada responden laki-laki dan perempuan menikah sebanyak 1.876 orang di Provinsi Banten pada Survei Demografi dan Kesehatan Indonesia 2012. Penelitian ini menggunakan rancangan cross sectional dengan analisis statistik menggunakan regresi logistik berganda. Hasil penelitian menunjukkan bahwa sikap setuju lebih diterima secara luas pada faktor individu (perempuan, orang berusia lebih muda, orang berpendidikan rendah, menikah muda, status ekonomi rendah, dan tinggal di pedesaan) dan faktor keluarga (pengambilan keputusan tunggal).
\end{abstract}

Kata kunci: Kekerasan Dalam Rumah Tangga, sikap setuju, regresi logistik, faktor individu, faktor keluarga, faktor masyarakat 


\section{Pendahuluan}

Kekerasan merupakan masalah kesehatan masyarakat yang utama di seluruh dunia. Salah satunya adalah kekerasan terhadap perempuan yang dilakukan oleh pasangannya yang bisa terjadi di semua negara, semua budaya, dan pada setiap tingkatan masyarakat tanpa kecuali (WHO, 2005). Berbagai teori dan penelitian dari berbagai negara telah menjelaskan bahwa kekerasan terhadap perempuan masih terjadi sampai saat ini. Menurut WHO (1997) dalam Ali \& Gavino (2008) data statistik yang tersedia dari seluruh dunia menunjukkan bahwa satu dari tiga perempuan mengalami kekerasan dalam hubungannya dengan suami/pasangan di beberapa waktu dalam masa hidupnya.

Dalam penelitian di India ditemukan prevalensi perempuan pernah menikah yang mendapatkan Kekerasan Dalam Rumah Tangga (KDRT) dari anggota keluarga, teman ataupun tetangga tercatat $54 \%$. Bahkan, $78 \%$ perempuan yang mendapatkan kekerasan menderita distress mental yang diakibatkan langsung dari tindak kekerasan tersebut. Lebih dari 70\% perempuan di Nepal juga melaporkan tindakan kekerasan yang dialaminya setiap tahun (CREA, 2002). Studi di beberapa negara yang berhasil mengumpulkan data lebih dari 24.000 perempuan dari 10 negara yaitu Bangladesh, Brasil, Ethiopia, Jepang, Namibia, Peru, Samoa, Serbia dan Montenegro, Thailand, dan Republik Tanzania menemukan $15-71 \%$ perempuan melaporkan pernah mendapatkan kekerasan dari pasangan sementara maupun suaminya (WHO, 2005).

Hasil pemetaan Komisi Nasional Anti Kekerasan Terhadap Perempuan (Komnas Perempuan) yang didukung oleh berbagai kelompok dan organisasi perempuan di seluruh Indonesia menunjukkan bahwa kasus penganiayaan terhadap perempuan di Indonesia persebarannya luas, jumlahnya terus berkembang, bentuknya beragam dan menimbulkan luka yang dalam. Dalam Catatan Akhir Tahun 2018, selama tahun 2017 di Indonesia ada 348.446 kasus kekerasan terhadap perempuan yang dilaporkan dan ditangani, yang terdiri dari 335.062 kasus bersumber pada data kasus/perkara yang tersebar di 34 provinsi. Seperti tahun sebelumnya kekerasan yang terjadi di ranah personal mencatat kasus paling tinggi. Pengadilan Agama mencatat ada sebanyak 335.062 kasus kekerasan yang terjadi di ranah personal terhadap istri. Data pengaduan langsung ke Komnas Perempuan juga menunjukkan tren yang sama, KDRT ranah personallain menempati posisi kasus yang paling banyak diadukan yaitu sebanyak 9.609 kasus (71\%) dari total 13.348 kasus yang masuk. Untuk kekerasan di ranah rumah tangga/relasi personal, kekerasan terhadap istri menempati peringkat pertama yaitu sebanyak 5.167 kasus. Di ranah rumah tangga/personal, persentase tertinggi adalah kekerasan fisik 41\% (3.982 kasus), diikuti kekerasan seksual 31\% (2.979 kasus), kekerasan psikis 15\% (1.404 kasus) dan kekerasan ekonomi 13\% (1.244 kasus) (Komnas Perempuan, 2018).

Kasus KDRT di Provinsi Banten tergolong tinggi. Sejak tahun 2010 hingga September 2017, terdapat sebanyak 442 kasus kekerasan terhadap perempuan dan anak terjadi di Banten. Jumlah tersebut terdiri dari KDRT sebanyak 154 kasus, perlindungan/penelantaran anak sebanyak 96 kasus, dan kekerasan seksual sebanyak 100 kasus. Hal tersebut diungkapkan Ketua Pusat Pelayanan Terpadu Pemberdayaan Perempuan dan Anak (P2TP2A) Provinsi Banten (Ridho, 2017).

Studi di negara industri dan negara berkembang menemukan alasan tetap yang menjadi pemicu tindak kekerasan terhadap perempuan dalam rumah tangga atau dalam hubungan intim yaitu perempuan tidak mematuhi atau bertengkar dengan suami/pasangan, bertanya kepada laki-laki tentang uang atau pacar, tidak memasak, tidak peduli dengan anakanak atau rumah, menolak berhubungan seks, dan perempuan dicurigai selingkuh (Krug et al., 2002). Banyak faktor telah dikaitkan dengan risiko lakilaki melakukan tindak kekerasan fisik terhadap pasangannya, di antaranya faktor individu (usia, pendidikan, dan otonomi keuangan); sejarah kekerasan dalam keluarga pasangan lakilaki (terutama setelah melihat ibunya sendiri dipukuli); pasangan (penyalahgunaan alkohol/ obat, dan pendidikan rendah), keluarga (sosial ekonomi dan dominasi laki-laki), dan masyarakat 
(gender, pembatasan hukum, dan pembatasan perempuan) (WHO, 2005).

Tindak kekerasan terhadap perempuan dapat membawa dampak merugikan bagi korbannya, seperti trauma fisik, psikis serta sosial yang mungkin akan berlangsung lama. Dampak kekerasan fisik berupa trauma fisik cenderung lebih mudah untuk disembuhkan, namun dampak kekerasan berupa trauma psikis atau sosial cenderung lebih sulit untuk disembuhkan bahkan mungkin akan memerlukan waktu yang lama. Bentuk-bentuk trauma psikis akibat kekerasan dapat berupa kecemasan, perasaan rendah diri, fobia hingga depresi. Akibat lebih lanjutnya adalah terganggunya fungsi sosial dan dapat berkembang menjadi permasalahan kesejahteraan sosial yang memerlukan perhatian khusus (Luhulima, 2000).

Kekerasan terhadap perempuan dalam rumah tangga yang sudah diangkat sebagai isu global sebenarnya sudah mendapatkan perhatian di Indonesia, terbukti dengan adanya Undang-Undang Nomor 23 Tahun 2004 tentang Penghapusan Kekerasan dalam Rumah Tangga (UU PKRT) (Rahayu, 2010). Namun dalam pelaksanaannya masih jauh dari harapan. Hal ini disebabkan adanya struktur sosial, sikap dan persepsi individu dan masyarakat (tentang perempuan dan tindak kekerasan terhadap perempuan) serta nilai masyarakat yang selalu ingin tampak harmonis sehingga sulit mengakui akan adanya masalah dalam rumah tangga apapun risikonya sehingga memerlukan bahasan tersendiri (Luhulima, 2000).

Kasus tindak kekerasan terhadap istri bukanlah kasus yang mudah terungkap. Banyak kasus yang tidak dilaporkan dan banyak kasus yang dalam perjalanannya dicabut oleh pelapor yang sekaligus juga korban. Hal ini dikarenakan banyaknya beban gender perempuan yang sering kali harus ditanggung sendiri dan kuatnya budaya patriarki, agama, dan adat yang menempatkan perempuan korban KDRT dalam situasi yang sulit untuk keluar dari lingkar kekerasan yang dialaminya, dan cenderung ragu untuk mengungkap fakta kekerasannya. Bahkan korban sulit mendapat dukungan dari keluarga maupun komunitas. Keyakinan "berdosa" jika menceritakan "kejelekan, keburukan, atau aib" suami membuat banyak perempuan korban KDRT menyimpan dalam-dalam berbagai bentuk kekerasan yang dialaminya (Rahayu, 2010).

Keyakinan yang dimiliki perempuan mengakibatkan adanya sikap pasrah dan menerima serta mempunyai perasaan wajib untuk rela menerima kekerasan dari suami. Saat kecil, ibu sudah mengajarkan bagaimana bersikap sopan terhadap saudara laki-laki. Menjelang dewasa, perempuan diberi pengertian mengenai sikap sopan terhadap suami. Laki-laki jarang diajarkan sikap sopan terhadap perempuan di rumah. Sikap ini diturunkan dari generasi ke generasi melalui sosialisasi peran ibu kepada setiap putrinya. Selain itu, budaya masyarakat yang patriarki turut menjadi penguat terjadinya kekerasan terhadap istri karena menempatkan posisi laki-laki lebih tinggi dibandingkan dengan perempuan, serta pandangan agama yang menempatkan laki-laki sebagai imam dalam rumah tangga (Selviana, 2010).

Sikap pasrah dari istri terhadap kekerasan dapat dilihat dalam studi banding yang dilakukan oleh Uthman, Lawoko, dan Moradi (2008) di 17 negara di Sub-Sahara Afrika di mana tindak kekerasan suami terhadap istri secara luas diterima dalam keadaan tertentu oleh lakilaki dan perempuan di semua negara yang diteliti. Perempuan lebih cenderung menyetujui tindak kekerasan dari pada laki-laki. Alasan "mengabaikan anak-anak" paling umum disetujui oleh perempuan dan laki-laki untuk membenarkan pemukulan. Alasan lainnya adalah "pergi tanpa memberitahu suami" dan "bertengkar dengan suami." Pihak yang menyetujui tindak kekerasan suami terhadap istri didominasi oleh kelompok usia muda, pendidikan rendah, sosial ekonomi rendah, tinggal di daerah pedesaan, akses ke media yang rendah dan pengambil keputusan tunggal. Penelitian mengenai sikap terhadap KDRT juga dilakukan oleh Marshall dan Furr (2010) pada perempuan di Turki. Hasil penelitian tersebut menunjukkan bahwa perempuan yang memiliki jumlah anak banyak, memegang nilai-nilai patriarki, menikah di usia yang lebih 
muda, menetap di pedesaan, dan menerima uang penggantian (lamaran) berhubungan dengan sikap setuju atas tindak pemukulan suami terhadap istri. Penelitian ini menekankan pada faktor yang membuat seseorang membenarkan satu bentuk KDRT.

Studi yang dilakukan Joshi (2011) terhadap perempuan di Kazakhstan, Kirgizstan, dan Tajikistan menunjukkan bahwa perempuan yang berpendidikan rendah, berasal dari beberapa kelompok etnis, mempunyai banyak anak, tinggal di daerah perkotaan, dan mempunyai status ekonomi menengah lebih cenderung menyetujui tindak KDRT.

Berdasarkan Survei Demografi dan Kesehatan Indonesia (SDKI) tahun 2012 ditemukan sikap terhadap KDRT meningkat proporsinya baik pada laki-laki maupun perempuan. Proporsi sikap perempuan pernah kawin yang menyetujui hak suami untuk memukul istri karena alasanalasan tertentu mengalami peningkatan dari $30,8 \%$ menjadi 34,5\%. Angka ini lebih tinggi dibandingkan dengan laki-laki kawin yang mencapai $16,3 \%$ menjadi $17,3 \%$. Rata-rata alasan yang paling tinggi adalah mengabaikan anak-anaknya, pergi tanpa memberitahu suami, bertengkar dengan suami, menolak hubungan seks, dan memasak makanan yang tidak bisa dimakan. Semakin meningkatnya sikap terhadap KDRT ini tentunya akan berdampak terhadap perilaku seseorang untuk melakukan KDRT.

Sikap individu tidak terlepas dari persepsi dan keyakinan sosial yang berkembang dalam masyarakat. Keyakinan sosial yang berkembang dalam masyarakat tentang kekerasan suami pada istri akan memengaruhi keyakinan individu, kemudian keyakinan tersebut memengaruhi sikap terhadap kekerasan suami pada istri, yaitu kecenderungan bersikap negatif atau bersikap positif. Sikap inilah yang akan memengaruhi seseorang untuk melakukan perilaku kekerasan. Berdasarkan uraian tersebut peneliti tertarik untuk melakukan penelitian dengan tujuan mengetahui faktor-faktor yang berhubungan dengan sikap setuju atas tindak kekerasan (pemukulan) suami terhadap istri dalam rumah tangga di Provinsi Banten tahun 2012.
Penelitian ini didasarkan pada analisis data sekunder SDKI tahun 2012 dengan menggunakan pendekatan cross sectional (potong lintang), di mana variabel-variabel yang termasuk faktor bebas (independent) dan faktor terikat (dependent) diobservasi sekaligus pada suatu saat. SDKI merupakan sebuah survei yang diselenggarakan oleh Badan Pusat Statistik (BPS) dan dilaksanakan setiap lima tahun sekali.

Survei ini diselenggarakan pada tahun 2012 oleh BPS bekerja sama dengan Badan Koordinasi Keluarga Berencana Nasional (BKKBN) dan Kementerian Kesehatan (Kemenkes). Secara teknis, BPS juga dibantu oleh United States Agency for International Development (USAID) melalui proyek Demographic and Health Surveys yang dilaksanakan oleh ORC Marco International, Inc. Penelitian tersebut diselenggarakan di 33 provinsi di Indonesia sejak tanggal 7 Mei hingga 31 Juli 2012. Sedangkan analisis data pada penelitian faktor yang memengaruhi sikap atas tindak kekerasan (pemukulan) suami terhadap istri dilakukan pada bulan Januari sampai Maret 2018 dengan menggunakan data sekunder SDKI 2012 yang diperoleh melalui proses perizinan. Populasi dalam penelitian ini adalah laki-laki kawin usia 15-54 tahun dan perempuan kawin usia 15-49 tahun di provinsi Banten di Indonesia pada tahun 2012. Sampel penelitian adalah laki-laki kawin usia 15-54 tahun dan perempuan kawin usia 15-49 tahun di provinsi Banten pada tahun 2012 yang menjadi responden pada saat pelaksanaan SDKI 2012. Setelah melalui proses seleksi sampel dari data SDKI 2012, maka jumlah sampel yang tersisa adalah 1.876. Desain penarikan sampel pada SDKI 2012 adalah two stage sampling. Hasil pengukuran yang diperoleh dari two stage sampling design memerlukan perlakuan khusus yang pengolahannya menggunakan perangkat lunak SPSS.

Analisis univariat digunakan untuk menggambarkan secara umum karakteristik subjek penelitian dan variabel-variabel yang diteliti baik independen maupun dependen. Hasilnya kemudian disederhanakan ke dalam bentuk yang mudah dibaca dan diinterpretasikan yaitu penyajian melalui tabel distribusi frekuensi, diagram, dan teks. 
Setelah diketahui karakteristik masingmasing variabel dapat diteruskan analisis lebih lanjut. Apabila diinginkan analisis hubungan antar dua variabel maka analisis dilanjutkan pada tingkat bivariat (Hastono, 2011). Analisis bivariat adalah analisis yang dilakukan terhadap dua variabel yang dianggap berhubungan atau berkorelasi. Analisis ini menggunakan uji regresi logistik sederhana karena dalam penelitian ini dilakukan untuk menguji mengenai perbedaan proporsi antara 2 variabel kategorik dan mengetahui adanya hubungan antara 2 variabel tersebut.
Analisis multivariat digunakan untuk mengetahui variabel independen mana yang paling besar pengaruhnya terhadap variabel dependen. Analisis multivariat yang digunakan adalah analisis regresi logistik ganda. Salah satu pendekatan model matematis yang digunakan untuk menganalisis hubungan satu atau beberapa variabel independen dengan sebuah variabel dependen kategorik yang bersifat data nominal (dikotom) (Hastono, 2011). Uji ini menggunakan model prediksi karena semua variabel indepeden dianggap sama penting sehingga proses estimasi dapat dilakukan dengan beberapa koefisien regresi logistik sekaligus.
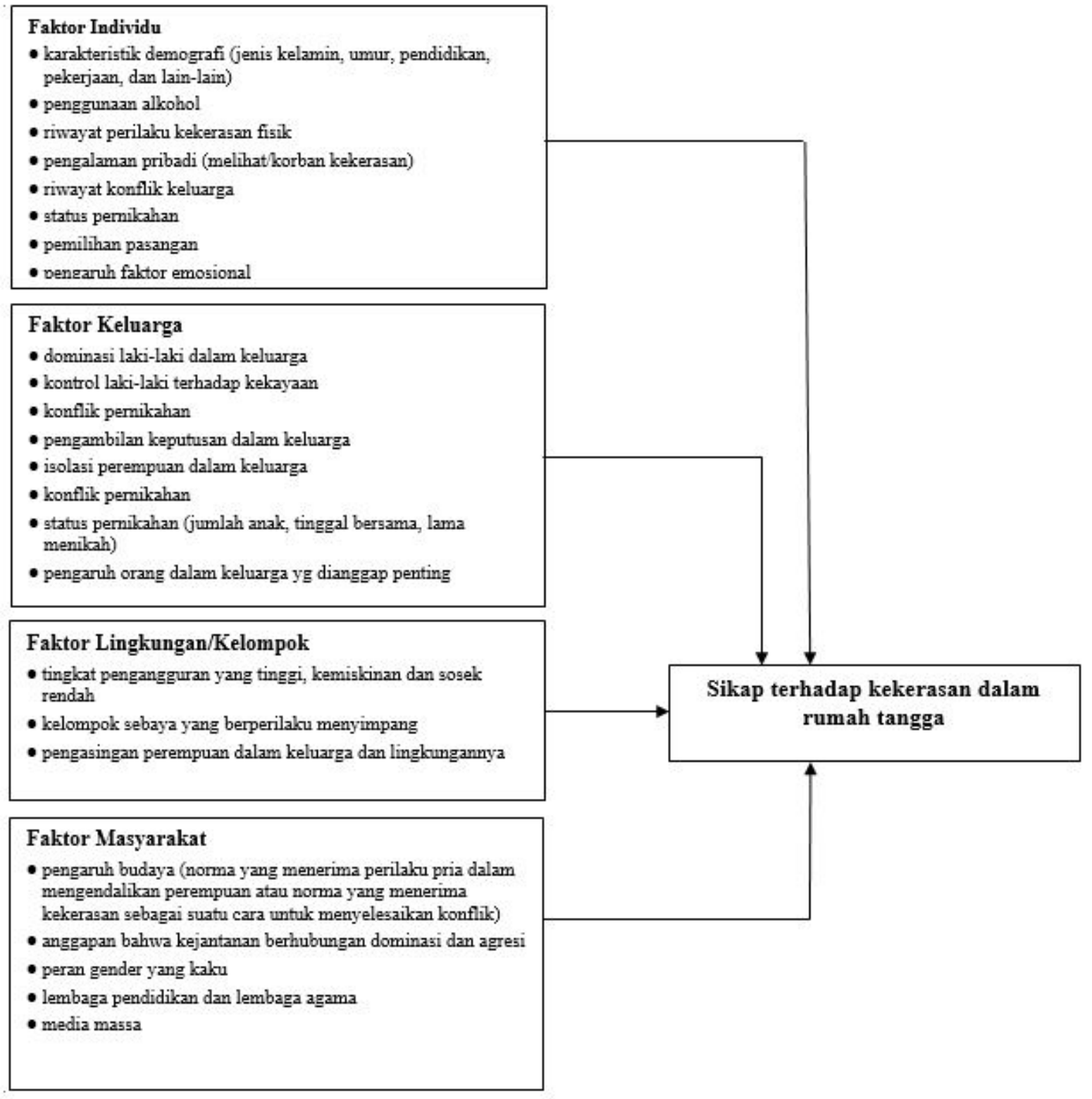

Bagan 1. Sikap terhadap Kekerasan dalam Rumah Tangga 


\section{Analisis Univariat, Bivariat dan Multivariat} Analisis Univariat

\section{a. Sikap terhadap Kekerasan dalam Rumah} Tangga

Jumlah sampel penelitian ini adalah 1.876 orang. Dari jumlah tersebut, sebanyak 27,4\% atau 514 orang menyatakan sikap setuju terhadap tindak KDRT. Di bawah ini merupakan tabel distribusi responden terhadap tindak KDRT di Provinsi Banten Tahun 2012:

Tabel 1. Distribusi Sikap Responden terhadap Tindak KDRT di Provinsi Banten tahun 2012

\begin{tabular}{lll}
\hline Sikap terhadap tindak KDRT & Jumlah (n) & Persentase \\
\hline Tidak setuju & 1.362 & 72,6 \\
Setuju & 514 & 27,4 \\
Total & 1.876 & 100 \\
\hline
\end{tabular}

b. Karakteristik Responden Berdasarkan Faktor Individu, Keluarga dan Masyarakat

Hasil penelitian disajikan secara deskriptif mengenai distribusi frekuensi dari variabel independen yang meliputi faktor individu, faktor keluarga, dan faktor masyarakat. Pada tabel 2 menunjukkan jumlah responden perempuan lebih banyak dibandingkan laki-laki. Sebagian responden berusia di atas 35 tahun.

Pendidikan responden sebagian besar adalah pendidikan rendah (47\%) dan sedang (40,9\%). Status pekerjaan responden lebih dari separuhnya bekerja $(60,8 \%)$. Sebagian status ekonomi responden di Provinsi Banten adalah teratas $(31,8 \%)$ dan menengah ke atas $(13,4 \%)$. Sebagian besar responden tinggal di pedesaan $(63,8 \%)$. Umur pertama menikah responden di Provinsi Banten sebagian pada umur $\geq 20$ tahun.

Tabel 3. Karakteristik Responden Berdasarkan Faktor Keluarga di Provinsi Banten Tahun 2012

\begin{tabular}{lll}
\hline Variabel & Jumlah $(\mathrm{n})$ & Persentase \\
\hline Hidup bersama & & \\
Tinggal bersama & 1.759 & 93,8 \\
Tinggal terpisah & 117 & 6,2 \\
Jumlah anak & & \\
Tidak punya & 135 & 7,2 \\
$1-2$ & 1.028 & 54,8 \\
$\geq 3$ & 713 & 38,0
\end{tabular}

Lama menikah

\begin{tabular}{lll}
$\geq 20$ tahun & 552 & 29,4 \\
10-19 tahun & 652 & 34,8 \\
$0-9$ tahun & 672 & 35,8 \\
Pengambil keputusan & & \\
Dengan pasangan/orang lain & 588 & 31,1 \\
Sendiri (suami/istri) & 1.288 & 68,7 \\
\hline
\end{tabular}

Berdasarkan faktor keluarga, Tabel 3 menunjukkan hampir semua responden tinggal bersama pasangannya. Jumlah anak yang dimiliki responden lebih dari separuhnya berkisar antara 1-2 orang. Proporsi lamanya menikah tampak merata di berbagai periode tahun dengan persentase tertinggi pada pernikahan 0-9 tahun. Dalam mengambil keputusan di keluarga kebanyakan masih dilakukan oleh responden atau pasangan sendiri.

Keterpaparan media massa merupakan variabel dari faktor masyarakat. Pada Tabel 4 terlihat responden yang terpapar media koran maupun radio mempunyai proporsi yang hampir merata. Pada media televisi sebagian besar responden terpapar.

Tabel 4. Karakteristik Responden Berdasarkan Faktor Masyarakat di Provinsi Banten Tahun 2012

\begin{tabular}{lll}
\hline Variabel & Jumlah $(\mathrm{n})$ & Persentase \\
\hline Paparan Koran & 1.048 & 55,9 \\
Terpapar & 828 & 44,1 \\
Tidak terpapar & & \\
Paparan Radio & 1.116 & 59,5 \\
Terpapar & 760 & 40,5 \\
Tidak terpapar & & \\
Paparan TV & 1.833 & 97,7 \\
Terpapar & 43 & 2,3 \\
Tidak terpapar & & \\
\hline
\end{tabular}

\section{Analisis Bivariat}

\section{a. Faktor Individu terhadap Sikap Kekerasan dalam Rumah Tangga}

Pada analisis bivariat antara faktor individu dengan sikap terhadap KDRT menunjukkan jenis kelamin, umur, pendidikan, pekerjaan, status ekonomi, tempat tinggal, dan umur pertama menikah berhubungan secara bermakna ( $\mathrm{p}$-value $<0,05)$. Responden perempuan cenderung bersikap menyetujui KDRT empat kali lebih 
besar dibandingkan dengan responden lakilaki. Responden yang berusia lebih muda (1524 tahun) mempunyai kecenderungan dua kali dibandingkan responden berusia $\geq 35$ tahun.

Proporsi yang menyetujui KDRT tampak merata pada responden yang berpendidikan tinggi, sedang dan rendah. Proporsi terkecil yang menyetujui KDRT adalah responden yang tidak sekolah. Proporsi responden tidak bekerja, lainlain dan tidak tahu yang bersikap setuju terhadap KDRT lebih besar dibandingkan responden yang bekerja. Proporsi sikap setuju KDRT pada responden menurut status ekonomi bervariasi, dengan proporsi sikap setuju KDRT terbesar pada status ekonomi terbawah.

Responden yang tinggal di pedesaan mempunyai proporsi sikap menyetujui KDRT yang lebih besar dibandingkan dengan di perkotaan. Umur pertama menikah pada responden yang berusia dini 10-15 tahun mempunyai proporsi yang yang lebih besar dengan responden yang berusia $\geq 20$ tahun.

\section{b. Faktor Keluarga terhadap Sikap Kekerasan dalam Rumah Tangga}

Hasil analisis bivariat antara faktor keluarga dengan sikap setuju KDRT pada Tabel 6 menunjukkan variabel yang berhubungan secara bermakna adalah hidup bersama, lama menikah dan pengambil keputusan. Responden yang tinggal terpisah cenderung 1,79 kali lebih menyetujui KDRT dibandingkan yang tinggal bersama. Responden dengan lama menikah singkat (0-9 tahun) lebih cenderung menyetujui KDRT dibandingkan responden dengan waktu menikah lebih lama ( $\geq 20$ tahun). Responden yang

Tabel 5. Faktor Individu terhadap Sikap Responden atas Tindak KDRT di Provinsi Banten Tahun 2012

\begin{tabular}{|c|c|c|c|c|}
\hline \multirow{2}{*}{$\begin{array}{c}\text { Variabel } \\
\text { Independen }\end{array}$} & \multicolumn{2}{|c|}{ Jumlah (n) } & \multirow{2}{*}{ OR } & \multirow{2}{*}{ P Value } \\
\hline & Tidak setuju (\%) & Setuju (\%) & & \\
\hline Jenis Kelamin & & & & 0,000 \\
\hline Laki-laki & 90,0 & 10,0 & 1.00 & \\
\hline Perempuan & 67,4 & 32,6 & $4,38(3,14-6,11)$ & \\
\hline Umur & & & & 0,000 \\
\hline$\geq 35$ & 77,9 & 22,1 & 1,00 & \\
\hline $25-34$ & 70,8 & 29,2 & $1,45(1,16-1,82)$ & \\
\hline $15-24$ & 56,6 & 43,3 & $2,70(2,01-3,64)$ & \\
\hline Pendidikan & & & & 0,000 \\
\hline Tinggi & 74,9 & 25,1 & 1,00 & \\
\hline Sedang & 72,1 & 27,9 & $1,15(0,79-1,67)$ & \\
\hline Rendah & 71,9 & 28,1 & $1,17(0,80-1,70)$ & \\
\hline Tidak sekolah & 84,3 & 15,7 & $0,55(0,24-1,27)$ & \\
\hline Pekerjaan & & & & 0,000 \\
\hline Bekerja & 75,0 & 25,0 & 1,00 & \\
\hline Tidak bekerja, lain-lain, tidak tahu & 68,8 & 31,2 & $1,40(1,11-1,67)$ & \\
\hline Status ekonomi & & & & 0,003 \\
\hline Teratas & 76,2 & 23,8 & 1,00 & \\
\hline Menengah ke atas & 74,6 & 25,4 & $1,09(0,82-1,44)$ & \\
\hline Menengah & 72,5 & 27,4 & $1,22(0,88-1,68)$ & \\
\hline Menengah ke bawah & 63,9 & 36,1 & $1,81(1,32-2,50)$ & \\
\hline Terbawah & 69,2 & 30,8 & $1,43(1,03-1,97)$ & \\
\hline Tempat tinggal & & & & 0,000 \\
\hline Perkotaan & 76,2 & 23,8 & 1,00 & \\
\hline Pedesaan & 66,3 & 33,7 & $1,63(1,32-2,00)$ & \\
\hline Umur pertama menikah & & & & 0,000 \\
\hline$\geq 20$ tahun & 77,1 & 22,9 & 1,00 & \\
\hline 16-19 tahun & 67,8 & 32,2 & $1,60(1,28-2,01)$ & \\
\hline 10-15 tahun & 67,5 & 32,5 & $1,63(1,22-1,17)$ & \\
\hline
\end{tabular}


Tabel 6. Faktor Keluarga terhadap Sikap Responden atas Tindak KDRT di Provinsi Banten

Tahun 2012

\begin{tabular}{|c|c|c|c|c|}
\hline \multirow{2}{*}{ Variabel Independen } & \multicolumn{2}{|l|}{ Jumlah (n) } & \multirow{2}{*}{ OR } & \multirow{2}{*}{$P$ Value } \\
\hline & Tidak setuju (\%) & Setuju (\%) & & \\
\hline Hidup bersama & & & & 0,004 \\
\hline Tinggal bersama & 73,4 & 26,6 & 1,00 & \\
\hline Tinggal terpisah & 60,7 & 39,3 & $1,79(1,22-2,63)$ & \\
\hline Jumlah anak & & & & 0,117 \\
\hline Tidak punya & 70,4 & 29,6 & 1,00 & \\
\hline $1-2$ & 71,0 & 29,0 & $0,97(0,65-1,44)$ & \\
\hline$\geq 3$ & 75,3 & 24,7 & $0,78(0,52-1,17)$ & \\
\hline Lama menikah & & & & \\
\hline$\geq 20$ tahun & 77,9 & 22,1 & 1,00 & \\
\hline 10-19 tahun & 71,8 & 28,2 & $1,39(1,07-1,80)$ & 0,002 \\
\hline $\begin{array}{l}\text { 0-9 tahun } \\
\text { Pengambil keputusan }\end{array}$ & 69,0 & 31,0 & $1,58(1,22-2,05)$ & \\
\hline Dengan pasangan/orang lain & 76,7 & 23,3 & 1,00 & 0,008 \\
\hline Sendiri (suami/istri) & 70,7 & 29,3 & $1,36(1,09-1,71)$ & \\
\hline
\end{tabular}

dalam mengambil keputusan sendiri memiliki kecenderungan untuk menyetujui KDRT 1,36 kali dibandingkan dengan responden yang hidup bersama.

\section{c. Faktor Masyarakat terhadap Sikap Kekerasan dalam Rumah Tangga}

Hasil analisis bivariat antara faktor masyarakat dengan sikap KDRT pada Tabel 7 menunjukkan tidak terdapat hubungan yang bermakna antara paparan koran, paparan radio, dan paparan televisi dengan sikap KDRT.

\section{Analisis Multivariat}

Analisis multivariat bertujuan untuk mengetahui hubungan antara variabel di tingkat individu, keluarga maupun masyarakat dengan sikap terhadap KDRT. Pada multivariat variabel independen yang mempunyai $p$ value $<0,25$ pada seleksi bivariat dimasukkan ke dalam model (lihat Tabel 8). Variabel yang tidak masuk seleksi adalah paparan TV. Evaluasi hubungan setiap variabel dengan sikap terhadap KDRT dilakukan dengan melihat nilai $p$ value. Variabel independen yang memiliki nilai $p$ value tertinggi dieliminasi dengan melihat kemaknaan batasan nilai $p$ value $<0,05$.

Pada Tabel 8 menunjukkan $p$ value terbesar adalah pekerjaan dengan $p$ value 0,633 sehingga variabel tersebut dikeluarkan. Pada model kedua (lihat lampiran) menunjukkan $p$ value terbesar adalah umur menikah $(0,586)$ sehingga variabel tersebut dikeluarkan.

Pada model ketiga menunjukkan $p$ value yang terbesar adalah jumlah anak $(0,451)$

Tabel 7. Faktor Masyarakat terhadap Sikap Responden atas Tindak KDRTdi Provinsi Banten Tahun 2012

\begin{tabular}{lllll}
\hline \multicolumn{1}{c}{$\begin{array}{c}\text { Variabel } \\
\text { Independen }\end{array}$} & \multicolumn{2}{c}{ Jumlah (n) } & \multirow{2}{*}{ OR } & \multirow{2}{*}{ P Value } \\
\cline { 2 - 3 } & Tdk setuju (\%) & Setuju (\%) & \\
\cline { 1 - 2 } $\begin{array}{l}\text { Paparan Koran } \\
\text { Terpapar }\end{array}$ & 74,4 & 25,7 & 1,00 & \\
Tidak terpapar & 70,4 & 29,6 & $1,22(0,99-1,49)$ & 0,066 \\
$\begin{array}{l}\text { Paparan Radio } \\
\text { Terpapar }\end{array}$ & & & & \\
Tidak terpapar & 74,2 & 25,8 & 1,00 & \multirow{2}{*}{0,069} \\
$\begin{array}{l}\text { Paparan TV } \\
\text { Terpapar }\end{array}$ & 70,3 & 29,7 & $1,22(0,99-1,49)$ & \\
Tidak terpapar & & & & \\
\hline
\end{tabular}


sehingga variabel ini keluar dari model. Model keempat $p$ value terbesar pada variabel paparan koran $(0,372)$ yang mengakibatkan variabel ini dikeluarkan dari model.

Pada model kelima didapatkan hidup bersama mempunyai $p$ value terbesar $(0,213)$ sehingga variabel ini dieliminasi. Model keenam didapatkan variabel yang terbesar adalah lama menikah dengan $p$ value 0,118 kemudian dieliminasi. Pada model ketujuh didapatkan $p$ value terbesar pada variabel paparan radio yaitu 0,070 sehingga variabel ini dikeluarkan yang menghasilkan model akhir pada Tabel 9.

Pada Tabel 9 menunjukkan model akhir yang menggambarkan hubungan faktor-faktor yang memengaruhi sikap terhadap KDRT yaitu jenis kelamin, umur responden, pendidikan, status ekonomi, tempat tinggal, pengambil keputusan, dan paparan radio. Responden perempuan cenderung empat kali bersikap menyetujui tindak KDRT dibandingkan responden laki-laki. Pada responden berumur $\geq 35$ tahun sebagai pembanding, responden berumur 15-24 tahun lebih cenderung bersikap membenarkan KDRT. Artinya semakin muda umur responden akan lebih cenderung membenarkan sikap KDRT. Pada tingkat pendidikan menunjukkan bahwa semakin rendah pendidikan semakin beresiko untuk menyetujui tindak KDRT. Berdasarkan status ekonomi, responden dengan ekonomi menengah cenderung lebih menyetujui KDRT dibandingkan dengan responden dengan status ekonomi teratas.

Responden yang tinggal di pedesaan cenderung menyetujui tindak KDRT 1,52 kali dibandingkan dengan responden yang tinggal di perkotaan. Responden lebih cenderung menyetujui KDRT 1,30 kali ketika dirinya atau pasangannya mengambil keputusan secara individual dibanding dengan responden yang mengambil keputusan bersama, baik dengan pasangan maupun orang lain dalam keluarga. Responden yang tidak terpapar media radio mempunyai kecenderungan untuk menyetujui KDRT dibandingkan yang tidak terpapar.

\section{Gambaran Sikap Terhadap Tindak Kekerasan}

Hasil penelitian ini menunjukkan besarnya persentase sikap setuju terhadap tindak KDRT di Provinsi Banten pada tahun 2012. Sesuai laporan Pusat Pelayanan Terpadu Pemberdayaan Perempuan dan Anak (P2TP2A) Provinsi Banten (Ridho, 2017) kasus KDRT dari tahun 2010 sampai September 2017 mengalami peningkatan. Laporan Catatan Akhir Tahun Komnas Perempuan tahun 2017 juga menyatakan adanya peningkatan kejadian KDRT dari tahun 2016 ternyata diikuti sikap yang positif terhadap KDRT. Hal ini menunjukkan adanya definisi yang sesuai menurut Allport dan Newcomb bahwa sikap merupakan kesiapan dan kecenderungan untuk berperilaku/ bertindak.

Tabel 8. Model Regresi Logistik 1

\begin{tabular}{|c|c|c|c|}
\hline Variabel Independen & OR & $(95 \%) \mathrm{CI}$ & P Value \\
\hline $\begin{array}{l}\text { Jenis Kelamin } \\
\text { Laki-laki } \\
\text { Perempuan }\end{array}$ & $\begin{array}{l}1,00 \\
4,06\end{array}$ & $2,81-5,88$ & 0,000 \\
\hline $\begin{array}{l}\text { Umur } \\
\geq 35 \\
25-34 \\
15-24\end{array}$ & $\begin{array}{l}1,00 \\
1,18 \\
2,18\end{array}$ & $\begin{array}{l}0,83-1,66 \\
1,29-3,67\end{array}$ & $\begin{array}{l}0,360 \\
0,003\end{array}$ \\
\hline $\begin{array}{l}\text { Pendidikan } \\
\text { Tinggi } \\
\text { Sedang } \\
\text { Rendah } \\
\text { Tidak sekolah }\end{array}$ & $\begin{array}{l}1,00 \\
0,33 \\
0,64 \\
0,88\end{array}$ & $\begin{array}{l}0,13-0,84 \\
0,40-1,04 \\
0,58-1,33\end{array}$ & $\begin{array}{l}0,020 \\
0,072 \\
0,542\end{array}$ \\
\hline $\begin{array}{l}\text { Pekerjaan } \\
\text { Bekerja } \\
\text { Tidak bekerja, lain-lain, tidak tahu }\end{array}$ & $\begin{array}{l}1,00 \\
0,95\end{array}$ & $0,75-1,19$ & 0,633 \\
\hline
\end{tabular}




\begin{tabular}{|c|c|c|c|}
\hline Variabel Independen & OR & $(95 \%) C I$ & P Value \\
\hline $\begin{array}{l}\text { Status ekonomi } \\
\text { Teratas } \\
\text { Menengah ke atas } \\
\text { Menengah } \\
\text { Menengah ke bawah } \\
\text { Terbawah }\end{array}$ & $\begin{array}{l}1,00 \\
0,99 \\
1,54 \\
1,11 \\
1,02\end{array}$ & $\begin{array}{l}0,64-1,55 \\
1,03-2,32 \\
0,76-1,60 \\
0,75-1,40\end{array}$ & $\begin{array}{l}0,989 \\
0,037 \\
0,593 \\
0,891\end{array}$ \\
\hline $\begin{array}{l}\text { Tempat tinggal } \\
\text { Perkotaan } \\
\text { Pedesaan }\end{array}$ & $\begin{array}{l}1,00 \\
1,39\end{array}$ & $1,05-1,82$ & 0,020 \\
\hline $\begin{array}{l}\text { Umur pertama menikah } \\
\geq 20 \text { tahun } \\
16-19 \text { tahun } \\
10-15 \text { tahun }\end{array}$ & $\begin{array}{l}1,00 \\
1,05 \\
1,22\end{array}$ & $\begin{array}{l}0,79-1,40 \\
0,82-1,81\end{array}$ & $\begin{array}{l}0,733 \\
0,321\end{array}$ \\
\hline $\begin{array}{l}\text { Hidup bersama } \\
\text { Tinggal bersama } \\
\text { Tinggal terpisah }\end{array}$ & $\begin{array}{l}1,00 \\
1,32\end{array}$ & $0,87-2,00$ & 0,188 \\
\hline $\begin{array}{l}\text { Jumlah anak } \\
\text { Tidak punya } \\
1-2 \\
\geq 3\end{array}$ & $\begin{array}{l}1,00 \\
1,32 \\
1,36\end{array}$ & $\begin{array}{l}0,85-2,05 \\
0,81-2,28\end{array}$ & $\begin{array}{l}0,221 \\
0,243\end{array}$ \\
\hline $\begin{array}{l}\text { Lama menikah } \\
\geq 20 \text { tahun } \\
10-19 \text { tahun } \\
0-9 \text { tahun }\end{array}$ & $\begin{array}{l}1,00 \\
1,37 \\
1,13\end{array}$ & $\begin{array}{l}0,95-1,98 \\
0,66-1,92\end{array}$ & $\begin{array}{l}0,090 \\
0,656\end{array}$ \\
\hline $\begin{array}{l}\text { Pengambil keputusan } \\
\text { Dengan pasangan/orang lain } \\
\text { Sendiri (suami/istri) }\end{array}$ & $\begin{array}{l}1,00 \\
1,32\end{array}$ & $1,04-1,67$ & 0,025 \\
\hline $\begin{array}{l}\text { Paparan Koran } \\
\text { Terpapar } \\
\text { Tidak terpapar }\end{array}$ & $\begin{array}{l}1,00 \\
1,13\end{array}$ & $0,86-1,50$ & 0,381 \\
\hline $\begin{array}{l}\text { Paparan Radio } \\
\text { Terpapar } \\
\text { Tidak terpapar }\end{array}$ & $\begin{array}{l}1,00 \\
1,19\end{array}$ & $0,92-1,54$ & 0,180 \\
\hline
\end{tabular}

Tabel 9 Model Akhir Regresi Logistik Multivariat

\begin{tabular}{lccc}
\hline Variabel Independen & OR & $(95 \%) \mathrm{CI}$ & P Value \\
\hline Jenis Kelamin & & & \\
Laki-laki & 1,00 & & \\
Perempuan & 4,13 & $2,93-5,81$ & 0,000 \\
Umur & & & \\
$\geq 35$ & 1,00 & & \\
$25-34$ & 1,23 & $0,97-1,56$ & 0,085 \\
$15-24$ & 1,91 & $1,40-2,63$ & 0,000 \\
Pendidikan & & & \\
Tinggi & 1,00 & & \\
Sedang & 0,36 & $0,15-0,88$ & 0,026 \\
Rendah & 0,71 & $0,46-1,11$ & 0,133 \\
Tidak sekolah & 0,89 & $0,59-1,34$ & 0,588
\end{tabular}




\begin{tabular}{lccc}
\hline Variabel Independen & OR & $(95 \%)$ CI & P Value \\
\hline Status ekonomi & & & \\
Teratas & 1,00 & & \\
Menengah ke atas & 1,09 & $0,71-1,68$ & 0,693 \\
Menengah & 1,61 & $1,08-2,40$ & 0,020 \\
Menengah ke bawah & 1,18 & $0,82-1,70$ & 0,380 \\
Terbawah & 1,03 & $0,76-1,40$ & 0,828 \\
Tempat tinggal & & & \\
Perkotaan & 1,00 & & \\
Pedesaan & 1,52 & $1,17-1,98$ & 0,002 \\
Pengambil keputusan & & & \\
Dengan pasangan/orang lain & 1,00 & & \\
Sendiri (suami/istri) & 1,30 & $1,03-1,64$ & 0,031 \\
\hline
\end{tabular}

Pada hasil penelitian didapatkan alasan yang paling banyak mendasari sikap setuju terhadap KDRT di Provinsi Banten yaitu mengabaikan anak (20,6\%) dan pergi tanpa izin suami (19,8\%). Jika dibandingkan dengan penelitian lain yang dilakukan menurut Hindin (2003), Marshall \& Furr (2010), dan Joshi (2011) persentase sikap terhadap KDRT ini lebih kecil. Pada penelitian yang dilakukan di Banten, persentase sikap menyetujui terhadap KDRT lebih besar dibandingkan dengan penelitian yang dilakukan oleh Selviana (2010) yaitu 18,4\%. Hal ini disebabkan karena pada penelitian ini sampel yang digunakan adalah perempuan dan laki-laki yang sudah menikah.

Berdasarkan alasan yang paling banyak digunakan, dapat dimungkinkan bahwa pembentukan sikap dipengaruhi oleh persepsi budaya patriarki di masyarakat yang sering menganggap bahwa kodrat perempuan adalah mendidik anak, merawat, serta mengolah kebersihan dan keindahan rumah tangga atau urusan domestik (Fakih, 1999 dalam Saraswati, 2006) sehingga pada saat kewajiban tersebut tidak dilakukan dan tidak sesuai maka hal itu dijadikan sebagai alasan yang kuat untuk menyetujui tindak KDRT. Selain itu, sikap ini dianggap wajar karena diyakini dengan bersikap seperti itu merupakan hak suami sebagai pemimpin dan kepala rumah tangga.

Tingginya sikap terhadap KDRT di masyarakat bahkan mengalami peningkatan menunjukkan negara belum mengatasi isu kekerasan terhadap perempuan di rumah tangga dengan sepenuhnya melalui pelaksanaan kebijakan yang jelas. Meskipun menurut laporan Komnas Perempuan ada sebanyak 73 terobosan kebijakan untuk pencegahan dan penanganan kekerasan terhadap perempuan, namun pelaksanaannya belum menyentuh masalah pokok terjadinya kekerasan terhadap perempuan. Bahkan menurut survei yang dilakukan Komnas Perempuan (2009) dalam pelaksanaannya masih banyak masyarakat yang belum tersosialisasi dengan kebijakan-kebijakan tersebut.

Pandangan masyarakat berupa hal yang terjadi dalam rumah tangga adalah suatu hal yang tabu, aib, dan sangat privat, yang tidak perlu intervensi dari pihak luar, termasuk jika masalah rumah tangga itu sebetulnya sudah merupakan bentuk kekerasan. Hal ini sangat diyakini oleh sebagian besar masyarakat Indonesia, sehingga hampir tidak pernah ada kejadian KDRT dilaporkan kepada pihak yang berwajib. Bahkan mungkin tidak diutarakan kepada pihak kerabat terdekat karena kuatnya keyakinan sebagai suatu aib atau tabu dan akhirnya KDRT menjadi hal yang sangat tertutup atau ditutup-tutupi. Pandangan yang berkembang ini ditambah dengan pengaruh budaya patriarki yang masih kental serta kurangnya sosialisasi kebijakan tentang KDRT mengakibatkan adanya pembentukan sikap pada diri seseorang bahwa kekerasan dianggap wajar. Memang perubahan sikap menyetujui terhadap tindak KDRT di tingkat individu tidak cukup mengubah perilaku meskipun sikap ini sangat berkaitan dengan pengalaman masa lalu yang dialaminya sehingga seharusnya dikaji secara mendalam tentang pengalaman yang dialami seseorang dalam hidupnya. 
Faktor yang Memengaruhi Sikap terhadap KDRT

Berdasarkan hasil analisis multivariat, variabel yang mempunyai hubungan yang signifikan terhadap KDRT di Provinsi Banten pada tahun 2012 adalah jenis kelamin, umur, pendidikan, status ekonomi, tempat tinggal, dan pengambil keputusan.

\section{Jenis Kelamin}

Berdasarkan penelitian ini, menunjukkan adanya hubungan yang bermakna di Banten tahun 2012. Hasil penelitian ini serupa dengan penelitian yang dilakukan Uthman, Lawoko, dan Moradi (2009) yang menyatakan adanya hubungan yang erat antara gender dan sikap kekerasan terhadap perempuan. Studi mereka menemukan bahwa jenis kelamin adalah prediktor yang paling penting dari sikap, dimana perempuan secara signifikan lebih mungkin membenarkan kekerasan dari pada laki-laki. Berbeda dengan penelitian yang dilakukan oleh Flood dan Pease (2009) yang menekankan bahwa menjadi lakilaki atau perempuan bukan menjadi prediktor sikap dari kekerasan, sebaliknya mereka melihat kesenjangan gender sebagai cerminan sikap terhadap peran gender dan norma seksual secara umum. Hal ini menunjukkan perbedaan gender sesungguhnya tidak menjadi masalah sepanjang tidak melahirkan ketidakadilan gender.

Sebagian besar negara berkembang yang masih menganut garis keturunan ayah (patriarki), beranggapan bahwa laki-laki mempunyai posisi yang lebih tinggi dibandingkan perempuan. Oleh karena itu, kedudukan serta perlakuan terhadap perempuan yang berkonotasi diskriminatif itu tidaklah tanpa proses yang panjang. Artinya melalui berbagai pengalaman yang memungkinkan karakteristik perempuan cenderung tidak diunggulkan sehingga muncul stereotip perempuan. Stereotip perempuan cenderung tidak menguntungkan perempuan. Misalnya posisi perempuan berada di bawah laki-laki, tidak penting, lemah, penakut dan sebagainya. Kenyataan demikian ini terjadi melalui proses yang sangat panjang baik lewat sosialisasi, penguatan, konstruksi sosial, kultural, keagamaan bahkan melalui kekuasaan negara. Oleh karena melalui proses yang panjang itulah, maka lama-kelamaan perbedaan gender antara laki-laki dan perempuan menjadi seolah-olah ketentuan Tuhan atau kodrat yang tidak dapat diubah lagi.

Kuatnya budaya patriarki mengakibatkan perbedaan gender berubah menjadi ketidakadilan gender yang tertanam kuat dalam nilai seseorang sehingga sebagian besar perempuan merasa harus menerima kedudukannya dalam rumah tangga. Selain itu, ketergantungan perempuan terhadap laki-laki dalam rumah tangga secara finansial ikut membuat perempuan tidak berdaya. Sikap pasrah dan menerima yang mengakibatkan seorang istri rela menjadi korban dan bersikap menyetujui tindak kekerasan dari suaminya.

Peran strategis perempuan sebagai pendidik utama dalam keluarga mampu memberikan kontribusi besar dalam mencetak generasi berikutnya. Jika dalam diri perempuan tersebut masih melekat sikap pasrah terhadap budaya patriarki dan ketidakadilan gender maka tidak menutup kemungkinan sikap ini akan diajarkan dan berlanjut kepada anak-anaknya dan seterusnya. Pemberdayaan di berbagai bidang dan tingkatan dapat menjadi salah satu sarana peningkatan kapasitas perempuan dalam merubah sikap dan persepsi dirinya tentang gender. Selain itu, upaya pemberdayaan perempuan dapat dilakukan untuk meningkatkan peran perempuan yang lebih baik lagi dalam rumah tangga. Misalnya melalui pelatihan untuk memperkuat perempuan dalam kepemimpinan dan pengambilan keputusan, meningkatkan akses pendidikan bagi perempuan dan anak perempuan, meningkatkan akses perempuan dan kontrol atas sumber daya ekonomi, meningkatkan akses perempuan terhadap informasi kesehatan dan kontrol perempuan atas tubuh mereka sendiri, dan meningkatkan harga diri perempuan dan kekuatan pribadi.

\section{Umur}

Hasil analisis pada Tabel 9 menunjukan bahwa sikap setuju KDRT paling banyak dimiliki oleh responden dengan umur 15-24 tahun dengan hasil OR 1,91 dan p-value $<0,05$ 
yang artinya ada hubungan yang bermakna antara umur dengan sikap menyetujui KDRT. Pada responden umur 23-34 tahun didapatkan nilai OR yang lebih kecil. Hal ini menunjukkan semakin muda umur responden maka semakin meningkat kecenderungan bersikap setuju terhadap KDRT.

Hasil yang sama menurut penelitian yang dilakukan oleh Hindin (2003), Gupta et all (2008), dan Uthman, Lawoko, dan Moradi (2009) menyatakan secara signifikan responden muda lebih mungkin bersikap dan melakukan kekerasan dibandingkan dengan responden yang lebih tua. Pada umur muda (15-24 tahun) sedang mengalami masa transisi dari remaja menuju masa kedewasaan. Menurut Hurlock (2000), masa ini merupakan masa perubahan nilai dan masa penyesuaian diri dengan cara hidup baru sehingga cenderung labil dalam menyikapi suatu hal. Hal ini dapat menjadi penyebab orang muda mempunyai sikap membenarkan KDRT sehingga pemahaman dan pendidikan tentang kekerasan sangat penting diberikan sejak dini.

\section{Pendidikan}

Berdasarkan penelitian ini terlihat bahwa adanya hubungan bermakna antara pendidikan dengan sikap terhadap KDRT. Semakin tinggi pendidikan seseorang maka kecenderungan sikap untuk menyetujui KDRT menurun. Hasil ini sesuai dengan temuan Uthman, Lawoko, dan Moradi (2009) yang menyatakan adanya hubungan yang positif antara pendidikan dengan sikap yaitu responden yang tidak sekolah lebih cenderung untuk bersikap menyetujui KDRT. Pustikasari (2013) dalam penelitiannya juga menyatakan perempuan yang mempunyai suami berpendidikan rendah mempunyai resiko dua kali untuk mengalami kekerasan dibanding dengan suami berpendidikan tinggi.

Hasil penelitian ini justru mempunyai hasil yang berbeda dengan penelitian yang dilakukan oleh Gupta et all (2008) di mana laki-laki yang berpendidikan sampai dengan 12 tahun cenderung dua kali untuk melakukan kekerasan dibanding laki-laki yang tidak sekolah atau sekolah kurang dari 11 tahun. Penelitian yang dilakukan oleh Selviana (2010) justru menunjukkan tidak ada perbedaan sikap secara signifikan ditinjau dari pendidikan responden.

Pendidikan tertinggi yang ditamatkan mempunyai peran yang sangat penting dalam pembentukan pola pikir seseorang. Seseorang dengan pendidikan yang semakin tinggi diasumsikan akan lebih mampu mengambil keputusan dan tindakan yang proporsional. Tindakan yang tidak saja menguntungkan diri sendiri, namun juga tidak merugikan orang lain maupun lingkungan. Mitos yang selama ini diyakini bahwa sikap dan perilaku kekerasan terhadap perempuan hanya terjadi di lingkungan yang kurang berpendidikan, namun ternyata cukup banyak perempuan korban yang berpendidikan tinggi. Hal ini disebabkan karena kurikulum di Indonesia sampai saat ini baik di tingkat pendidikan dasar sampai perguruan tinggi sekalipun masih bias gender. Pendidikan formal yang ada juga belum mampu menjawab kebutuhan spesifik perempuan sehingga pendidikan formal yang tinggi sekalipun tidak mampu membebaskan perempuan dari persoalan-persoalan diskriminasi perempuan termasuk KDRT.

Pendidikan merupakan kunci terwujudnya keadilan gender dalam masyarakat, karena pendidikan merupakan alat untuk mentransfer norma-norma masyarakat, pengetahuan dan kemampuan mereka. Dengan kata lain, lembaga pendidikan merupakan sarana formal untuk sosialisasi sekaligus transfer nilai-nilai dan normanorma yang berlaku dalam masyarakat, termasuk nilai dan norma gender. Untuk itu sejak awal perlu diupayakan terwujudnya pemahaman gender di tingkat pendidikan anak usia dini dan salah satunya di tingkat menengah (Adriana, 2009).

Kebijakan kurikulum tentang gender memang harus menjadi suatu intervensi. Namun sampai saat ini belum terwujud karena banyak pertimbangan seperti padatnya mata pelajaran yang diberikan di tingkat pendidikan. Sebenarnya dalam pelaksanaannya tidak harus tertuang dalam mata pelajaran tersendiri namun bisa diintegrasikan dalam mata pelajaran yang sudah ada tanpa mengubah kurikulum yang berlaku, tidak menambah alokasi waktu, materi yang dikembangkan kontekstual dan faktual serta 
dapat diintegrasikan ke dalam indikator atau kegiatan pembelajaran. Berdasarkan hal tersebut seorang guru dituntut harus mempunyai strategi mewujudkan pembelajaran yang peka gender. Guru harus berperspektif gender, karena guru adalah ujung tombak pendidikan.

\section{Status Ekonomi}

Status ekonomi mempunyai hubungan yang bermakna dengan sikap KDRT. Artinya semakin rendah status ekonomi responden maka semakin tinggi kecenderungan untuk bersikap menyetujui KDRT. Hasil ini sama dengan hasil penelitian yang dilakukan oleh Hindin (2003), Gupta et all (2008), dan Uthman, Lawoko, dan Moradi (2009), dan Pustikasari (2013) yang menyatakan adanya kecenderungan sikap untuk menyetujui tindak kekerasan pada keluarga dengan status ekonomi yang menurun.

Kompleksitas kehidupan dan beban hidup yang terlalu berat dapat mengakibatkan ketidakseimbangan emosi hingga memicu terjadinya tindakan KDRT. Kerana itu, seluruh anggota dalam suatu keluarga sesuai kesanggupan masing-masing harus melakukan usaha-usaha yang dapat memperkuat fondasi dan struktur bangunan ekonomi keluarga. Tanggung jawab utama mencari nafkah memang kewajiban suami. Namun, istri sebagai anggota utama keluarga yang kedua juga dapat melakukan hal yang sama seperti suaminya, terlebih bila dia juga ikut bekerja dalam sektor formal atau informal. Selain itu juga agar istri lebih berdaya dan tidak terlalu bergantung secara ekonomi terhadap suami.

Meskipun berdasarkan penelitian lebih banyak responden dengan ekonomi rendah bersikap menyetujui KDRT namun pada saat terjadinya perilaku KDRT tidak menutup kemungkinan terjadi pada responden dengan status ekonomi menengah ke atas. Keluarga menengah ke atas lebih sadar hukum sehingga punya keberanian melapor ke lembaga terkait. Oleh karenanya, jika dibandingkan persentase sikap dengan perilaku KDRT bisa saja berbeda. Selain itu, kasus KDRT pada lapisan ini terjadi karena adanya perubahan gaya hidup dalam rumah tangga, kehidupan yang mewah dan materialistis yang sekarang ini mulai berkembang di masyarakat.

\section{Tempat Tinggal}

Berdasarkan hasil penelitian ini didapatkan hubungan yang bermakna antara daerah tinggal dengan sikap KDRT. Di mana responden yang tinggal di pedesaan mempunyai kecenderungan untuk membenarkan KDRT. Hindin (2003), dan Uthman, Lawoko, dan Moradi (2009) juga menyatakan hasil yang sama dalam penelitiannya. Penelitian lain yang juga menunjukkan bahwa budaya patriarki dan wilayah pedesaan dapat memengaruhi pembentukan sikap pada perempuan Turki (Marshall dan Furr, 2010).

Peningkatan kecenderungan ini disebabkan masih kentalnya budaya nenek moyang yang dipegang oleh masyarakat pedesaan terutama budaya patriarki. Hal ini mengakibatkan terbentuknya kecenderungan sikap setuju menjadi lebih besar dan meningkat. Selain itu, faktor keterbatasan informasi, status ekonomi, pekerjaan, dan pendidikan di pedesaan ikut berperan juga dalam menentukan sikap. Dalam lingkup masyarakat desa perlu ada wadah atau kelompok yang peduli terhadap permasalah perempuan. Sarana ini akan menjadi perantara dan sosialisasi bagi perempuan dalam mengetahui dan memperoleh hak kesetaraan dan keadilan melalui lembaga litigasi. Tanpa adanya wadah atau kelompok yang berfungsi sebagai perantara dan sosialisasi tentang kekerasan, sulit bagi perempuan untuk memahami dan mengakses serta menggunakan hak mereka untuk mendapatkan perlindungan hukum. Hal ini disebabkan oleh pengetahuan yang terbatas serta adanya keengganan dan ketakutan untuk berhubungan dengan dunia luar.

Menurut Tamtiari (2005) masyarakat pedesaan sangat menghormati tokoh masyarakat, tokoh agama dan tokoh adat sebagai panutan. Jika pemahaman mereka salah tentang gender, salah pula dalam manifestasi kehidupan sehariharinya. Kesalahan pemahaman ini berakibat pada pandangan laki-laki terhadap perempuan yang sangat merendahkan. Penyadaran akan pentingnya permasalahan KDRT di kalangan masyarakat pedesaan perlu ditingkatkan agar 
upaya eliminasi dapat berjalan dari para pelaku itu sendiri dan bukan dari pihak lain. Upaya perubahan yang berasal dari dalam atau secara internal lebih efektif dibandingkan upaya yang dilakukan pihak luar. Langkah awal mengubah perspektif para tokoh panutan masyarakat ini diharapkan dapat mengubah pola perilaku mereka menjadi sensitif gender sehingga dapat mempengaruhi pola perilaku masyarakat secara umum. Jika panutan masyarakat yaitu tokoh agama, tokoh adat dan tokoh yang lain sudah mempunyai pandangan yang peduli akan pentingnya mengubah perilaku yang mengarah pada KDRT. Selanjutnya dilakukan pembiasaan diri untuk melakukan hal tersebut dalam tindakan nyata yang dapat dijadikan contoh. Tidak hanya sebatas kata-kata, tetapi perbuatan sudah mengarah ke sana. Dengan demikian sedikit demi sedikit masyarakat dapat diarahkan untuk menghargai perempuan.

\section{Pengambil Keputusan}

Untuk mengukur partisipasi dalam pengambilan keputusan di rumah tangga, penulis hanya menggunakan pertanyaan yang mengambil keputusan dalam perawatan kesehatan responden dan melakukan pembelian keperluan rumah tangga untuk keperluan barang tahan lama. Berdasarkan Tabel 9 pengambil keputusan mempunyai hubungan yang signifikan. Hali ini dapat diartikan bahwa responden yang mengambil keputusan sendiri (suami/istri) mempunyai kecenderungan untuk bersikap setuju terhadap KDRT. Hasil ini sama dengan penelitian yang dilakukan oleh Uthman, Lawoko, dan Moradi (2009) dan Pustikasari (2013).

Dalam budaya di Indonesia, peran perempuan adalah sebagai ibu dan istri yang bertanggung jawab terhadap rumah tangga sedangkan suami lebih berperan untuk mencari nafkah. Pembagian peran ini berpengaruh terhadap pengambilan keputusan dan ikut memengaruhi seseorang dalam bersikap terhadap KDRT. Salah satu faktor yang memengaruhi keterlibatan istri pada pengambilan keputusan adalah struktur peran suami atau istri. Struktur peran suami atau istri yaitu bagaimana cara pandang suami tentang pemahaman kesetaraan gender yang ada dalam rumah tangga, bagaimana suami memandang peran suami dan istri setara atau tidak. Pemahaman suami tentang kesetaraan gender itu menjadi suatu permasalahan apabila suami memandang peran suami dan istri tidak setara karena itu dapat melahirkan ketidakadilan terhadap kaum perempuan (Fakih, 2003). Intervensi yang mempromosikan perlunya pengambilan keputusan bersama mungkin dapat meningkatkan pandangan kaum perempuan menuju kesetaraan dalam pernikahan sekaligus mempromosikan pandangan pria bahwa sengketa rumah tangga harus diselesaikan dengan negosiasi bukan dengan kekerasan.

\section{Penutup \\ Simpulan}

Pada faktor individu, sikap setuju terhadap sikap KDRT lebih diterima secara luas pada kelompok perempuan, berusia lebih muda, status pendidikan rendah, status ekonomi rendah, dan tinggal di pedesaan. Pada faktor keluarga, sikap setuju terhadap sikap KDRT lebih diterima responden dengan pengambil keputusan tunggal. Pada faktor masyarakat, keterpaparan media massa (koran, radio, dan televisi) mempunyai hubungan yang tidak bermakna dengan sikap setuju atas KDRT.

\section{Saran}

Saran yang dapat diberikan dari penelitian ini kepada pemerintah Provinsi Banten dan sektor terkait adalah memperkuat upaya proaktif sosialisasi tentang pencegahan KDRT dan kebijakan secara menyeluruh engan kerja sama lintas sektor di berbagai bidang kehidupan. Selain itu, juga segera merealisasikan kebijakan wajib belajar 12 tahun, karena kegiatan sekolah dapat menjadi salah satu alternatif untuk menunda pernikahan dini dan meningkatkan pemberdayaan perempuan.

Pendekatan terhadap tokoh masyarakat dan tokoh agama terutama di daerah pedesaan sebaiknya lebih ditingkatkan karena tokoh masyarakat merupakan individu yang mempunyai kemampuan untuk mengembangkan wacana gender melalui kiprahnya dalam dunia yang secara khusus digeluti. Sikap dan pandangan para tokoh masyarakat dalam hal ini merupakan 
indikator bahwa jika tokoh masyarakat memiliki kesadaran kesetaraan dan keadilan gender yang rendah, maka kesadaran masyarakat juga masih rendah karena pandangan para tokoh sangat berpengaruh terhadap pandangan masyarakat umumnya.

Upaya kampanye isu KDRT kepada masyarakat sebaiknya dilakukan secara lebih intensif dengan pola pendekatan individu, keluarga, kelompok dan masyarakat dan sesuai budaya masyarakat setempat. Peningkatan pemberdayaan perempuan juga dapat dilakukan untuk meningkatkan peran dan kedudukannya dalam keluarga melalui pelatihan di bidang ekonomi, pertanian, keterampilan, dan lain-lain yang lebih merata di berbagai tempat terutama di daerah yang masih kental budaya patriarki.

Bagi bidang keilmuan, upaya memasukkan kurikulum mengenai gender dan KDRT mulai dari tingkat SD sampai dengan perguruan tinggi. Materi tersebut bisa diberikan secara terintegrasi dengan mata pelajaran/kuliah lainnya. Pendidik/guru harus mempunyai pengetahuan dan berperspektif gender untuk menunjang pembelajaran yang peka gender. Dalam bidang pendidikan kesehatan (keperawatan, kebidanan, kedokteran, kesehatan masyarakat, dan lain-lain) menjadikan isu gender dan KDRT sebagai salah satu mata kuliah wajib tersendiri sehingga dapat dijadikan dasar dalam memberikan konseling, penyuluhan, dan penanganan kasus KDRT di masyarakat untuk menunjang pelayanan kesehatan.

\section{DAFTAR PUSTAKA}

\section{Jurnal}

Adriana, I. (2009). Kurikulum Berbasis Gender (Membangun Pendidikan yang Berkesetaraan). Tadris. Volume 4. No. 1. 137-152.

Ali, P.A. \& Gavino, M.I.B. (2008). Violence Against Women in Pakistan: A Framework for Analysis." Journal of Pakistan Medical Association 58 (4), 198-203. https://doi.org/10.1590/b808323a.
Gupta, J., Silverman, J.G., Hemenway, D., AcevedoGarcia, D., Stein D.J., \& Williams, D.R. (2008). Physical Violence Against Intimate Partners and Related Exposures to Violence Among South African Men. Canadian Medical Association Journal, 179, 6. http://www.cmaj.ca/ content/179/6/535.long. Diakses 31 Januari 2018.

Hindin, M.J. (2003). Understanding Women's Attitudes towards Wife Beating in Zimbabwe. Bulletin of the World Health Organization, 81:501-508. https://doi.org/10.1590/S004296862003000700008

Selviana, M. (2010). Sikap Istri terhadap Kekerasan dalam Rumah Tangga (Studi Di Wilayah Kampung ' $\mathrm{X}$ ' Jakarta). Jurnal Psikologi Volume 8 Nomor 1. 16-24

Uthman, A., Lawoko, S., \& Moradi, T. (2009). Factors Associated with Attitudes towards Intimate Partner Violence against Women: a Comparative Analysis of 17 Sub-Saharan Countries. BMC International Health and Human Rights, 9 (1). https://doi.org/10.1186/1472-698X-9-14.

\section{Buku}

Badan Pusat Statistik (BPS), Badan Kependudukan dan Keluarga Berencana Nasional (BKKBN), Kementerian Kesehatan (Kemenkes), dan ICF International. (2013). Indonesia Demographic and Health Survey 2012. Jakarta: BPS, BKKBN, Kemenkes and ICF International.

Fakih, M. (2003). Analisis Gender dan Transformasi Sosial. Yogyakarta: Pustaka Pelajar.

Hastono, S.P. (2011). Analisis Data Kesehatan. Depok: FKM UI.

Hurlock, E.B. (2000). Psikologi Perkembangan Suatu Pendekatan Sepanjang Rentang Kehidupan. Edisi VI. Jakarta: Erlangga.

Krug, E.G., et al. (2002). World Report on Violence and Health. Geneva: World Health Organization.

Luhulima, A.S. (2000). Pemahaman Bentuk-Bentuk Tindak Kekerasan terhadap Perempuan dan Altematif Pemecahannya. Jakarta: Kelompok Kerja Convention Wacth Pusat Kajian Wanita dan Jender, Universitas Indonesia.

Pusat Pelayanan Terpadu Pemberdayaan Perempuan dan Anak (P2TP2A). (2008). Buku Panduan Petugas Kesehatan dalam Penanganan Korban Kekerasan Terhadap Perempuan dan Anak. Jakarta: P2TP2A. 
Saraswati, R. (2006). Perempuan dan Penyelesaian Kekerasan dalam Rumah Tangga. Bandung: PT. Citra Aditya Bakti.

Tamtiari, W. (2005). Awig-awig Melindungi Perempuan dari Kekerasan dalam Rumah Tangga. Yogyakarta: Pusat Studi Kependudukan dan Kebijakan Universitas Gadjah Mada.

\section{Tesis}

Pustikasari, A. (2013). "Dampak Pernikahan Dini terhadap Kekerasan dalam Rumah Tangga pada Istri di Kabupaten Bekasi Tahun 2013." Tesis. Fakultas Kesehatan Masyarakat Universitas Indonesia.

\section{Internet}

CREA. (2002). "Count Me in. Research Report Violence against, Disabled, Lesbian, and Sew Working Women in Bangladesh, India and Nepal". http://www.creaworld.org/files/ cmir. Diakses 10 Januari 2018.

Flood, M. \& Pease, B. (2009). "The Factors Influencing Community Attitudes in Relation to Violence against Women : a Critical Review of the Literature. Paper Three of the Violence Against Women Community Attitudes Project 3." Victoria, Vichealth. http://www. vichealth.vic.gov.au/cas. Diakses 16 Januari 2018.

Joshi, M. (2011). Attitudes Towards WifeBeating among Women in Kazakhstan, Kyrgyzstan, and Tajikistan. An Empirical Examination Using Multiple Indicator Cluster Surveys. http://search.proquest.com/ docview/908432142/fulltextPDF/25E73C 326CEC4CEDPQ/10? accountid=17242. Diakses 21 April 2018.
Komnas Perempuan. (2018). "Lembar Fakta Catatan Tahunan Komnas Perempuan Tahun 2018, Tergerusnya Ruang Aman Perempuan dalam Pusaran Politik Populisme." Maret 7, 2018. https:/www.komnas perempuan. go.id/ file/pdf_file/2018/ SIARAN\%20PERS $\% 20$ 2018/Lembar\%20Fakta\%20Catahu\%20 7\%20Maret\%202018.pdf. Diakses 21 April 2018.

Marshall, G. A \& Furr, L.A. (2010). "Factors that Affect Women Attitudes Toward Domestic Violence in Turkey." http://search.proquest. $\mathrm{com} /$ docview/28796149? accountid $=17242$. Diakses 1 Februari 2018.

Rahayu, N. (2010). "Undang-Undang No. 23 Tahun 2004 tentang Penghapusan Kekerasan dalam Rumah Tangga (UU-PKDRT)." http:// ditjenpp. kemenkumham.go.id/hukumpidana/653-undang-undang-no-23-tahun2004-tentang-penghapusan-kekerasandalam-rumah-tangga-uu-pkdrt.html. Diakses 4 Januari 2018.

Ridho, Rasyid. (2017). "Kasus Kekerasan terhadap Perempuan dan Anak di Banten Tinggi.” Kamis, 12 Oktober 2017. https:// daerah.sindonews.com/ read/1247756/174/ kasus-kekerasan-terhadap-perempuan-dananak-di-banten-tinggi-1507799997. Diakses 4 Januari 2018.

WHO. (2005). "WHO Multi-country Study on Women's Health and Domestic Violence against Women". http://whqlibdoc.who.int/ publications/2005/9241593512_eng.pdf. Diakses 30 Januari 2018. 